\title{
What made the Monster? Lack of Communicative Competence \& Communication
}

\author{
Taejin Koh \\ Associate Professor, Department of Hindi, Hankuk University of Foreign Studies, Korea. \\ Orcid: oooo-0002-9025-80oX. Email: tjindia@naver.com
}

Received January 14, 2018; Revised April 20, 2018; Accepted April 30, 2018; Published May 26, 2018.

\begin{abstract}
This paper attempts to interpret Mary Shelly's Frankenstein from a linguistic point of view. In other words, it discusses why a creature was forced to become the monster with a perspective of communicative competence. The first part of the paper briefly describes Mary Shelly's family background and talks about linguistic points. The second part analyses the relationship between the monster and his language in relation to the learning process of the language. It also elaborates about the communicative competence. Mary Shelley might pose us a question through the monster's experience: how his relationship with humans should be based on communication? Then the third part gives us the idea that how this tragic story unfolds Victor Frankenstein's complete alienation from the society. It seems that Mary Shelley has already warned people of the danger of a lone wolf with scientific advances. In conclusion, the paper stresses the importance of communicative competence based on the frame of the style.
\end{abstract}

Keywords: Frankenstein, communication, communicative competence, linguistic competence, monster

\section{Introduction}

Although Horace Walpole's The Castle of Otranto (1764) is generally regarded as a pioneer of the Gothic novel, it is also agreed that Mary Shelly, one of the $19^{\text {th }}$ century writers, is considered as the pioneer of today's science fiction horror novel. Mary included many significant elements of the Gothic novel such as horror, romance, death, supernatural things, insanity, curse and so on. It is also useful to know the meaning of 'Gothic' in order to understand what Gothic fiction is like. The word 'Gothic' originated from the Northern European tribes, the 'Goths' who plundered Rome in the medieval age; so, it was treated as barbaric and destructive. Thus Goths were recognized as an object of terror at that time. Punter (1996) mentioned the features of the Gothic one by one:

Where the classical was well-ordered, the Gothic was chaotic; where simple and pure, Gothic was ornate and convoluted; where the classics offered a set of cultural models to be followed, Gothic represented excess and exaggeration, the product of the wild and the uncivilized (Punter, 1996, p.5).

Gothic fiction is grouped by shared characteristics- the barbaric, crudity, supernatural power, fomentation of fear, unordinary settings etc. Ann Radcliffe's The Mysteries of Udolpho (1794) and Matthew Lewis's The Monk (1796) are generally accepted

(C) AesthetixMS 2018. This Open Access article is published under a Creative Commons Attribution Non-Commercial 4.0 International License (http://creativecommons.org/licenses/by-nc/4.0/), which permits non-commercial re-use, distribution, and reproduction in any medium, provided the original work is properly cited. For citation use the DOI. For commercial re-use, please contact editor@rupkatha.com. 
as representatives of the Gothic novels with The Castle of Otranto. However, Mary Shelley's Frankenstein marked the beginning of a new era with a new horror evoked by the human agency and its scientific powers in that genre. Thus Frankenstein is truly distinct from other classical Gothic fictions. Mary put the science of the day into the novel. Unlike the elements of classical Gothic fiction, this novel horrifies the readers with the protagonist's desire, conflict, appearance, lack of communication, prejudice, etc., and it also inheres the tradition of Gothic fiction in which man's hidden passions erupt in horror.

Frankenstein is a masterpiece that cannot even be imagined before the age which was dominated by the worldview of the creation of God. The novels after Frankenstein imply the problem of remarking people in the modern world (Baldick, 1987, p.142). But it began to draw attention in the 2oth century, and Frankenstein has been researched or analyzed in many different directions. Mary's Frankenstein has long been a favorite text for psychoanalytic literary criticism as well as feminist critics (Poovey 1980; Wright 1986; Gilbert \& Gubar 1990; Kotze 2000). Psychoanalytic approaches such as Freudian and Lacanian, and Marxist criticism have also been adopted to analyze it.

As an approach to communicative competence, this paper talks about the interrelationship between human and non-human beings as well as between the protagonists and their society. It examines how lack of communication and communicative competence ultimately lead to their destruction. It is worth noting that the monster has learned or acquired or stolen languages to communicate with human beings. In addition, other protagonists such as Victor Frankenstein and Robert Walton have also suffered from the loneliness and lack of communication. In fact, Frankenstein is full of anger, repentance, and ignorance; and the reason that causes Victor Frankenstein's and the monster's tragedy is that of their blind pursuit along with lack of communication.

Let us briefly describe Mary Shelly's background in order to see why she or Victor Frankenstein created the monster, and why this novel appeared in front of the readers. The full name of Mary Shelly is Mary Wollstonecraft Shelley, but she is often called Mary Wollstonecraft Godwin. We can indirectly look at her family background through these two names. She was a daughter of William Godwin (1756-1836), an English journalist, philosopher and novelist, and Mary Wollstonecraft (1759-1797), a leading feminist British writer. Her husband, Percy Bysshe Shelley (1792-1822), was one of the major English Romantic poets. Her parents were radical thinkers and Mary Shelly had chances to meet the contemporary outstanding elites who were her father's friends such as Samuel Taylor Coleridge, William Wordsworth, and William Hazlitt and this helped Mrs. Shelly to develop her own critical way of thinking. After her mother Mary Wollstonecraft died of puerperal fever, her father remarried Mars Clairmont who was cruel to Mary. Since Mary felt lonely, she started reading books, especially the writings of her mother. Moreover, Mary got into the habit of seeking consolation and companionship from her mother's spirit. It is just like Victor Frankenstein in her novel, whodoes teach himself scientific knowledge and literature, and learns by himself. Moreover, the time that Mary spent with 
the Baxters, in fact, the happiest moment she had never before, might have inspired her depiction of the De Lacey family in Frankenstein.

It is often argued that the creature in Frankenstein is considered as a metaphor for the author's experience of postpartum trauma. It is said, considering Mary's life, that the creation of the creature in her work represents her fear of childbirth (Johnson, 1982, p.9). Mary Shelley suffered a miscarriage that threatened her life and in the intervening years, she lost her favorite child, William Shelley, and her daughter, Clara (Rauch, 1995, p.239). Mores (1976) points out that Mary was neither secure nor lawful as she felt guilty and failed to fulfill her role as a mother (1976, pp.92-93). Mary might have expressed the importance of home for the birth of a healthy child. However, Bewell (1988) argues that these claims are not irrelevant to Mary's experience (1988, p.121). Considering French Revolution and the Enlightenment in Europe at the time, the creature can represent the working-class while Victor can be a representation of aristocratic oppression of the Ancien Régime(Brantlinger, 1996, p.1996). From a feminist point of view, the creature is symbolized as a woman who resists patriarchal dogmatism (Smith, 2000, p.245). Rauch (1995) argues that the monstrous creature is the perfect embodiment of Knowledge.

Many critics have given various symbolic meanings to the creatures called monsters. In other words, they have analyzed the symbolism of the monsters in consideration of Marry Shelly's electrical life, the social system of the time, and the psychology of the writer. It also describes the nature of the creature by describing many love affairs depicted in the novel in relation to the creature. This study, however, intends to examine why the creature became the monster and the symbolism of the creature itself in terms of communication and communicative competence.

\section{The Monster and Communicative Competence}

It is also interesting to explore the meaning of the subtitle of the novel, 'The Modern Prometheus'. Prometheus is the Greek Titan, cultural hero and trickster figure who is credited with the creation of man from clay, and who defies the gods by stealing fire and giving it to humanity. What the monster, in the novel, tried to steal from human beings may be referred as the ability of communication without getting permission from the creator, Victor Frankenstein. The monster might have stolen the language from humans, but it did not learn how to use it. He knew only a language, but no communicative skill. A language does not have only a function of communication but also a function of social relationships to be had in the contextual situation. Dell Hymes (1966) proposed the term 'communicative competence' meaning that it is accounted sufficiently for the social and functional rules of a language. It is a concept that includes not only the grammatical knowledge of a particular language but also the ability to use the language appropriately, according to the social context. This new wave of interest was distinguished between linguistic competence and communicative competence:

The linguistic competence of a human being should accordingly be identified with that individual's internalized 'program' for production and recognition. While 
many linguists would identify the study of this program with the study of performance rather than competence, it should be clear that this identification is mistaken since we have deliberately abstracted away from any consideration of what happens when a language user actually attempts to put the program to use. A major goal of the psychology of language is to construct a viable hypothesis as to the structure of this program to use (Kac, 1992, pp.52-53).

While linguistic competence refers to the ideal system of linguistic knowledge that enables speakers to spell out and understand grammatical sentences in a language, communicative competence is related to the codes of a language, a linguistic repertoire, and speaking styles shared by members of the speech community. It is relative, not absolute. Hymes (1966) addressed Chomsky's (1965) abstract notion of competence and proposed the ethnography of communication as an approach towards analyzing communication within the wider context of the social and cultural practices and beliefs of the members of a particular culture of a speech community. It is a communicative skill needed to interact in everyday social situations.

The monster in Frankenstein might have been successful in learning a language used by humans. After he was abandoned by the creator, Victor Frankenstein, he discovered the human language while he was hiding himself in the De Lacey family cottage:

By degrees, I made a discovery of still greater moment. I found that these people possessed a method of communicating their experience and feelings to one another by articulate sounds. I perceived that the words they spoke sometimes produced pleasure or pain, smiles or sadness, in the minds and countenances of the hearers. This was indeed a godlike science, and I ardently desired to become acquainted with it. But I was baffled in every attempt I made for this purpose. Their pronunciation was quick, and the words they uttered, not having any apparent connection with visible objects, I was unable to discover any clue by which I could unravel the mystery of their reference. (Chapter 12. p. 130)

Humans have their language to convey their thoughts, experiences, and feelings among themselves. And the monster finally realizes, at that moment, that a language is something with which humans can express their feelings to one other. A language is a very important factor that determines human identity. A human language is a godlike science that enables creation and birth. The monster has a desire to have language for the first time. Therefore the monster constantly strives to have it after discovering a language of human beings. Because he might have thought that if he had language, he could communicate with humans, and be like a human being. However, the monster thought that there is no relationship between what people articulate and visible objects. So he could not learn their language even though he knew that a language is a godlike science:

By great application, however, and after having remained during the space of several revolutions of the moon in my hovel, I discovered the names that were given to some of the most familiar objects of discourse; I learned and applied the 
words, 'fire,' 'milk,' 'bread,' and 'wood.' I learned also the names of the cottagers themselves. The youth and his companion had each of them several names, but the old man had only one, which was 'father.' The girl was called 'sister' or 'Agatha,' and the youth 'Felix,' 'brother,' or 'son.' I cannot describe the delight I felt when I learned the ideas appropriated to each of these sounds and was able to pronounce them. I distinguished several other words without being able as yet to understand or apply them, such as 'good,' 'dearest,' 'unhappy.' (Chapter 12, pp. 130131).

The monster finally came to know the meaning of the name and was able to distinguish some words from their usage. So, he enjoyed the taste of language for the first time. But it was not enough to talk to someone; so he had to learn more to get into the human world. His language learning process took place through a stealthy life in the De Lacey family cottage. He observed the De Lacey family life and listened to their language through a hole in the barn. In the meantime, he finally learned the function and role of human language and realized it by understanding the arbitrary relationship between pronunciation and its representation. He felt that a language is a means to explain the world, and also realized the sophistication and variety of language. He believed that if he had mastered the language, he would be able to communicate equally with humans without being ignored by his ugly appearance.

"These thoughts exhilarated me and led me to apply with fresh ardour to the acquiring the art of language. My organs were indeed harsh, but supple, and although my voice was very unlike the soft music of their tones, yet I pronounced such words as I understood with tolerable ease. It was as the ass and the lap-dog; yet surely the gentle ass whose intentions were affectionate, although his manners were rude, deserved better treatment than blows and execration (Chapter 12. pp. 134-135)

The love and respect of humans seem to be sweet to the monster, and for the first time ever the monster felt love for others. The creature read the books such as Sorrows of Werther, Paradise Lost, Plutarch's Lives which he had picked up in the forest. He also realized that a language is a necessary tool to experience human love. The monster is now definitely motivated why he should learn a language. He studied a language to socialize himself with the people at the cottage. But, in fact, it is imitation, not learning or acquisition. At that time people believed that a language was learned by imitation. The imitation is like a process in which a child imitates the language of an adult. A language cannot be learned through imitation (Skinner, 1957), whereas in Frankenstein, the monster began to learn language by imitating the De Lacey family. But there is something the author has overlooked. A Language is not a product of learning on its own. Humans can learn a language by communicating and making relations with each other.

"My days were spent in close attention, that I might more speedily master the language; and I may boast that I improved more rapidly than the Arabian, who understood very little and conversed in broken accents, whilst I comprehended and could imitate almost every word that was spoken. "While I improved in 
speech, I also learned the science of letters as it was taught to the stranger, and this opened before me a wide field for wonder and delight (Chapter 13. pp. 139140).

The Monster finally learned a language and accumulated knowledge through the language. The speed is faster than humans, and the monster himself is surprised to learn his language. The interesting point is that he began to view the world differently through the language. In fact, he tried to learn a language to simply communicate with humans and to feel love with humans. But after mastering the language, his attitude toward the world began to change. Probably with regard to the effects of language learning, the power was given to the monster to expand his knowledge so greatly just as Prometheus brought fire to man.

"Every conversation of the cottagers now opened new wonders to me. While I listened to the instructions which Felix bestowed upon the Arabian, the strange system of human society was explained to me. I heard of the division of property, of immense wealth and squalid poverty, of rank, descent, and noble blood.

"The words induced me to turn towards myself. I learned that the possessions most esteemed by your fellow creatures were high and unsullied descent united with riches. A man might be respected with only one of these advantages, but without either, he was considered, except in very rare instances, as a vagabond and a slave, doomed to waste his powers for the profits of the chosen few! And what was I? Of my creation and creator, I was absolutely ignorant, but I knew that I possessed no money, no friends, no kind of property. I was, besides, endued with a figure hideously deformed and loathsome; I was not even of the same nature as man. I was more agile than they and could subsist upon coarser diet; I bore the extremes of heat and cold with less injury to my frame; my stature far exceeded theirs. When I looked around I saw and heard of none like me. Was I, then, a monster, a blot upon the earth, from which all men fled and whom all men disowned? "I cannot describe to you the agony that these reflections inflicted upon me; I tried to dispel them, but sorrow only increased with knowledge (Chapter 13. p. 141).

The monster not only changed his view of the world but also began to think about his identity. He started to feel self-conscious about himself, 'what was I?' Eventually, by learning the language, the monster kept asking about his identity and became aware of discontinuity and loneliness about his difference with a human being. Furthermore, the monster's self-consciousness becomes more apparent through the confirmation of the absence of his name.

"But where were my friends and relations? No father had watched my infant days, no mother had blessed me with smiles and caresses; or if they had, all my past life was now a blot, a blind vacancy in which I distinguished nothing. From my earliest remembrance, I had been as I then was in height and proportion. I had never yet seen a being resembling me or who claimed any intercourse with me. 
What was I? The question again recurred, to be answered only with groans (Chapter 13. pp 142-143).

Every being in the world has a name. So, the monster has to have a name. The absence of the name shows that it was abandoned thoroughly from the beginning. This novel may have been written on the assumption that the monster can never assimilate or communicate with human beings as a name was not given to the monster at the beginning of the epoch, and the monster did not have a name until the end. Names are the first step in the process of communication. When a mother calls a child or when a child calls her mother, a title is used. But even though the monster learned the language, he did not even have a name to indicate who he was. Perhaps, the fact that he did not have a name made him more isolated than his appearance. The monster also learned about the social class, conflicts, and absurdities of human beings through the language. A language might never have been sweet to him. The monster might not have had hatred and malice if he did not know the language. He who believed that everything would be solved through the language would eventually become frustrated with his identity through the language, and he also found that there was a gap between him and human beings.

Everything is related in them which bears reference to my accursed origin; the whole detail of that series of disgusting circumstances which produced it is set in view; the minutest description of my odious and loathsome person is given, in language which painted your own horrors and rendered mine indelible. I sickened as I read. 'Hateful day when I received life!' (Chapter 15. p. 154-155).

The monster got to know his birth story from Victor's diary. Some papers did not mean anything to the monster until he was able to decipher it. But after he had known the characters of the languages, a written language, he realized that his birth or presence had no value. After he came to know that his presence to the creator as well as to humans was disgusting, he asked the creator to create a female life as a reward for a solitude that was forsaken by the creator and humans. The monster needed a colleague to share his feelings. He learned the language and wanted to share and communicate emotions through the language.

"You must create a female for me with whom I can live in the interchange of those sympathies necessary for my being. This you alone can do, and I demand it of you as a right which you must not refuse to concede (Chapter 17. P. 174)."

It is a figure of the monster who became conscious of knowing the language and wanted to love like a human being. Although the monster had the same linguistic competence as humans have, it was essentially blocked from communication with humans. His language skill is linguistics competence, not communicative competence. What he needed was not a reading power nor speaking power but communication power. Communication can move people to do things without any doubt. But it should be developed by the relationship with respect and love. A language is a cooperative tool of action undertaken by people based on mutual deliberation. It was an unfortunate start for 
him to learn the language alone in the beginning. One who learns a language alone can never communicate with others.

\section{Victor Frankenstein and Communication}

In Mary Shelley's work, Victor Frankenstein is described as a natural philosopher or a scientist. However, the term 'scientist' was introduced and used in 1834 (Chapple, 1986). Frankenstein tries to utilize his academic knowledge not only to contribute to a society but also to fulfill his own intellectual desires. However he is not satisfied with the material object of the human body and he creates a new life that transcends life and death, and good and evil. The process of the creation of a new species may be similar with the Roman myth of Prometheus. Frankenstein's creature is a close similar with Prometheus as a creator of man. Rauch (1995) says that Mary Shelley's association of Frankenstein's science with magic may be an indicator of the unconventionality of his scientific practice and frame of mind (1995, p.233). Frankenstein was deeply enamored of a beautiful dream of being 'creator'. He longed to be like a god, but a scientist without any prior consideration of the ethics would only bring a tremendous wave. This new creature created by Frankenstein was the monster with ugly appearance, and rather than being helpful to society it became a source of fear and anxiety for all the spiritual values and material foundations of society. The monster was stronger than humans, and had the ability to easily acquire a language and knowledge. The monster was, in fact, assembled from the parts of dead bodies and strange chemicals. A lightning spark animated the monster. But Frankenstein immediately abandoned it out of disgust because he eventually felt fear and guilt rather than joy for creating a new life. Moreover he did not name his creation, and could not be able to control it.

The voyager, Robert Walton, introduced the power of Victor Frankenstein's fluent words in the letter. His speech is persuasive and touching. In addition, it is also described that Walton was fascinated by Frankenstein because Frankenstein had insights and knowledge not only in science but also in literature. As we have seen, Frankenstein was surely an intellectual and emotional person. But despite his excellent eloquence, he himself had a big problem in communication because of selfishness and pride.

Our conversations are not always confined to his own history and misfortunes. On every point of general literature, he displays unbounded knowledge and a quick and piercing apprehension. His eloquence is not forcible and touching; nor can I hear him, when he relates a pathetic incident or endeavours to move the passions of pity or love, without tears. What a glorious creature must he have been in the days of his prosperity, when he is thus noble and godlike in ruin! He seems to feel his own worth and the greatness of his fall (Chapter 24. p. 261).

He reminds me how often the same accidents have happened to other navigators who have attempted this sea, and in spite of myself, he fills me with cheerful auguries. Even the sailors feel the power of his eloquence; when he speaks, they no longer despair; he rouses their energies, and while they hear his voice they 
believe these vast mountains of ice are mole-hills which will vanish before the resolutions of man. These feelings are transitory; each day of expectation delayed fills them with fear, and I almost dread a mutiny caused by this despair (Chapter 24. p. 264).

The monster is also very good at eloquence. Frankenstein warned the captain to be careful of the monster. It is a warning about the dangers hidden behind the brilliant speech of the monster. The monster had fluent speech like his creator. Even though both the creator and the creature were excellent in eloquence, both of them did not have communicative competence. They did not know the true value of language and seemed to be not good at communication.

He is eloquent and persuasive, and once his words had even power over my heart; but trust him not. His soul is as hellish as his form, full of treachery and fiend-like malice (Chapter 24. p. 259).

Through his self-centered obsession with the unexpected life, he alienated his own creature. Victor Frankenstein's alienation may confirm his inevitable destruction. After his second encounter with the monster, he was no longer able to find any kind of consolation from the society. His disconnection from the society is a series of terrible loneliness. Fear of thorough isolation and loneliness eventually ends in tragedy. Perhaps, Frankenstein became hopeless, like a monster, since he did not hear from his family, and did not speak to anyone. In the end, the absence of communication made him a monstrous self, and he created a creature that resembles himself.

But I have one want which I have never yet been able to satisfy, and the absence of the object of which I now feel as a most severe evil, I have no friend, Margaret: when I am glowing with the enthusiasm of success, there will be none to participate my joy; if I am assailed by disappointment, no one will endeavor to sustain me in dejection. I shall commit my thoughts to paper, it is true; but that is a poor medium for the communication of feeling. I desire the company of a man who could sympathize with me, whose eyes would reply to mine. You may deem me romantic, my dear sister, but I bitterly feel the want of a friend. I have no one near me, gentle yet courageous, possessed of a cultivated as well as of a capacious mind, whose tastes are like my own, to approve or amend my plans. How would such a friend repair the faults of your poor brother! I am too ardent in execution and too impatient of difficulties (Letter 2. p. 7).

Frankenstein 's love also did not come to an end, but he loved Elizabeth Lavenza. His loss of her mother, however, eventually led him to a breakup with the world as well as Elizabeth. He dismissed contact with his beloved family and friends and devoted himself to research. But this breakup with the world finally leads to the tragic ending. The absence of communication is not only the production of the monster but also the transfer of oneself to the road of destruction.

Victor Frankenstein might be the only person who could communicate with his creation. The monster and Victor Frankenstein became outcasts who are tortured by their 
isolation caused by their own passions. After the death of Victor Frankenstein, the monster finally suffered from the extreme loneliness and helplessness. It is not much different from Mary's birth of a child without marriage.

\section{Conclusion}

Even Frankenstein was published two hundred years ago, it is still being circulated. However, it did not attract much attention at the time of its publication. Although Frankenstein has been so far considered the first science fiction, it was regarded as a minor novel for a long time because people treated this work as a non-canonical text (Smith, 2000, p.190). In the nineteenth century, art and technology were not sharply separated, and there was a mixture of philosophers who wanted to form a system of new ideas, explorers seeking the continent of unknown truth, and experimenters and artists who created new things. In these times many stories on new knowledge had been published.

Frankenstein presents us with more topics we have to think today as life sciences and genetic engineering become the keywords of the era. This novel may tell many issues such as consciousness, ethical values, life dignity, alienation, communication, and so on. In particular, the novel also directly deals with issues of status and class, communication with society, bioethics, and lonely wolves, the identity of human beings and so on. This paper has looked into the issue of the language with the aspects of communicative competence and communication.

This fiction has been framed in an epistolary style. It is not unilateral or authoritative but interrelated. In other words, the author wrote the fiction with the purpose of communicating with the readers. The work is apparently a collection of letters from Robert Walton. Walton wrote, in detail, to his sister what he has been through in his exploration. However, the story of the Victor Frankenstein and the monster lies in the form of a picture frame in the letter. Interestingly, his sister does not appear at all in the novel; in addition, she does not respond at all. So perhaps the author wanted that the letters from Walton might be for anonymous readers, not for his sister. Therefore, this novel may be based on the problem of communication.

\section{Acknowledgment}

This work was supported by Hankuk University of Foreign Studies Research Fund of 2017.

\section{References}

Baldick, Chris. (1987). In Frankenstein's Shadow: Myth, Monstrosity, and Nineteenth-Century Writing. Oxford: Clarendon.

Bewell, Alan. (1988). An Issue of Monstrous Desire: Frankenstein and Obstetrics. Yale Journal of Criticism, 
2(1), 105-128.

Brantlinger, Patrick. (1996). The Reading Monster. In J. Paul. Hunter (ed.), Frankenstein: The 1818 Text, Contexts, Criticism. New York: Norton, 468-476.

Chapple, J. A. V.. (1986). Science and Literature in the Nineteenth Century. Basingstoke: Macmillan.

Chomsky, Noam, (1965). Aspects of the Theory of Syntax. Cambridge: M.I.T. Press.

Gibert, Sandra M. \& Gubar, Susan. (1990). Mary Shelley's monstrous Eve. In Sage, Victor (ed.), The Gothic novel: a casebook. London: Macmillan, 150-162.

Hymes, Dell. (1966). Two types of linguistic relativity. In Bright, W. (ed.), Sociolinguistics. The Hague: Mouton, 114-158.

Johnson, Barbara. (1982). My monster / My Self. Diacritics, 12, 2-10.

Kac, Maichael. B. (1992). Grammars and Grammaticality. Amsterdam: John Benjamins Publishing.

Kotze, H. (2000). Desire, gender, power, language: a psychoanalytic reading of Mary Shelley's Frankenstein. Literator, 21(1), 53-68.

Mores, Ellen. (1976). Female Gothic. In Ellen Mores (ed.), Literary Women. New York: Doubleday, 87-99.

Rauch, Alan. (1995). The Monstrous Body of Knowledge in Mary Shelley's Frankenstein. Studies in Romanticism, 34(2), 227-253.

Poovey, Mary. (1980). My hideous progeny: Mary Shelley and the feminization of Romanticism. Publications of the Modern Language Association of America, 95, 332-345.

Punter, David. (1996). The Literature of Terror: A History of Gothic Fictions from 1765 to the present day. Vol 1. The Gothic Tradition. Harlow: Longman Group.

Shelly, Marry. (1818). Frankenstein. Retrieved on 15/11/2017 from https://www.planetebook.com/ebooks/Frankenstein.pdf

Skinner B. F. (1957). Verbal behavior. New York: Appleton-Century-Crofts.

Smith, Johanna M. (200o). A Critical History of Frankenstein, In Johanna M. Smith (ed.), Frankenstein. Boston: Bedford/St. Martin's, 237-261.

Wright, Elizabeth, (1986). Modern psychoanalytic criticism, In Jefferson, Ann \& Robey, David (eds.), Modern literary theory: A Comparative Introduction. London: Batsford, 145-165. 